University of Nebraska - Lincoln

DigitalCommons@University of Nebraska - Lincoln

Publications, Agencies and Staff of the U.S.

Department of Commerce

U.S. Department of Commerce

2011

\title{
Ontogenetic dietary information of the California sea lion (Zalophus californianus) assessed using stable isotope analysis
}

Anthony J. Orr

NOAA, tony.orr@noaa.gov

Seth D. Newsome

University of Wyoming

Jeffrey L. Laake

NOAA

Glenn R. VanBlaricom

University of Washington - Seattle Campus

Robert L. DeLong

NOAA

Follow this and additional works at: https://digitalcommons.unl.edu/usdeptcommercepub

Part of the Environmental Sciences Commons

Orr, Anthony J.; Newsome, Seth D.; Laake, Jeffrey L.; VanBlaricom, Glenn R.; and DeLong, Robert L., "Ontogenetic dietary information of the California sea lion (Zalophus californianus) assessed using stable isotope analysis" (2011). Publications, Agencies and Staff of the U.S. Department of Commerce. 301. https://digitalcommons.unl.edu/usdeptcommercepub/301

This Article is brought to you for free and open access by the U.S. Department of Commerce at DigitalCommons@University of Nebraska - Lincoln. It has been accepted for inclusion in Publications, Agencies and Staff of the U.S. Department of Commerce by an authorized administrator of DigitalCommons@University of Nebraska - Lincoln. 
MARINE MAMMAL SCIENCE, **(*): ***_*** (*** 2011)

(C) 2011 by the Society for Marine Mammalogy

DOI: $10.1111 / j .1748-7692.2011 .00522 . x$

\title{
Ontogenetic dietary information of the California sea lion (Zalophus californianus) assessed using stable isotope analysis
}

\author{
ANTHONY J. ORR \\ The National Marine Mammal Laboratory, \\ Alaska Fisheries Science Center, NOAA, \\ 7600 Sand Point Way NE, \\ Seattle, Washington 98155, U.S.A. \\ and \\ Washington Cooperative Fish and Wildlife Research Unit, \\ School of Aquatic and Fishery Sciences, \\ University of Washington, \\ Seattle, Washington 98195, U.S.A. \\ E-mail: tony.orr@noaa.gov \\ Seth D. Newsome \\ Department of Zoology and Physiology, \\ University of Wyoming, \\ 1000 East University Avenue, Department 3166 , \\ Laramie, Wyoming 82071, U.S.A.

\section{JEFFREY L. LAAKE} \\ The National Marine Mammal Laboratory, \\ Alaska Fisheries Science Center, NOAA, \\ 7600 Sand Point Way NE, \\ Seattle, Washington 98155, U.S.A. \\ GlenN R. VANBlaricom \\ Washington Cooperative Fish and Wildlife Research Unit, \\ School of Aquatic and Fishery Sciences, \\ University of Washington, \\ Seattle, Washington 98195, U.S.A. \\ ROBERT L. DeLong \\ The National Marine Mammal Laboratory, \\ Alaska Fisheries Science Center, NOAA, \\ 7600 Sand Point Way NE, \\ Seattle, Washington 98155, U.S.A.
}

\begin{abstract}
We used stable carbon $\left(\delta^{13} \mathrm{C}\right)$ and nitrogen $\left(\delta^{15} \mathrm{~N}\right)$ isotopes to examine ontogenetic dietary changes in 289 California sea lions (Zalophus californianus) at San Miguel Island, California during 2004-2007. Tissues analyzed included fur, red
\end{abstract}


blood cells, plasma, and serum. For all tissues, pups had higher $\delta^{15} \mathrm{~N}$ values and lower $\delta^{13} \mathrm{C}$ values compared to adults, which indicated that pups were feeding higher trophically than older conspecifics and on a lipid-rich milk diet prior to weaning. Yearling $\delta^{15} \mathrm{~N}$ values were slightly lower than pup or nearly indistinguishable from adult values depending on the tissue analyzed, indicating a dietary shift from maternal dependency to independent foraging. Juveniles (2-4 yr) and adults $\left(>4 \mathrm{yr}\right.$ ) had similar $\delta^{15} \mathrm{~N}$ values indicating they fed at a similar trophic level. There did not appear to be a pronounced dietary shift in $\delta^{13} \mathrm{C}$ values. However, $\delta^{13} \mathrm{C}$ values integrated with telemetry data indicated that postweaned individuals fed in similar foraging areas. Dietary changes during early life stages may be due to differences in physiology, morphology, experience, or energetic requirements; however, young animals are able to attain the skills needed to consume adult prey types near the end of their second year of life.

Key words: diet shift, otariids, stable isotopes, Zalophus californianus.

For otariid pinnipeds, like all other air-breathing homeotherms that forage in the aquatic environment, there is a separation between air at the surface and their prey located in the water column. Therefore, the development of foraging is highly dependent on the development of diving in these animals (Horning and Trillmich 1997a). The physiological factors that limit dive duration are positively correlated with body size and age (Horning and Trillmich 1997b, Burns 1999). Oxygen stores increase with body mass (Schmidt-Nielsen 1984, Kooyman 1989, Fowler et al. $2007 a$ ) and are depleted faster in smaller animals because of a higher mass-specific rate of metabolism (Kleiber 1975, Thorson and Le Boeuf 1994). Additionally, swimming speed and traveling distance increase with size and age of several pinniped species (e.g., Feldkamp et al. 1989, Baker and Donohue 2000, Fowler et al. 2007b). As a result, young individuals theoretically are more limited in the depths they can dive (aerobically), the durations that they can stay underwater, or the types of prey items (e.g., slower prey) that they are able to exploit. Other factors, such as experience, sex, and reproductive status, might also influence the diving and foraging patterns of pinnipeds. For example, nursing females are restricted in duration by their pups' fasting abilities to forage close to rookeries (Melin et al. 2000). These differences in physiology, morphology, and energetic requirements among different age classes of otariids presumably result in different patterns in diet and habitat use.

Stable isotope analysis (SIA) is a method to characterize diet and dietary variation because it is based on the premise that the stable isotope composition of a consumer's diet is reflected in its tissues (DeNiro and Epstein 1978, Peterson and Fry 1987). SIA provides less specific information on diet composition and diversity compared to fecal analysis, rather it provides information on assimilated food over multiple timescales depending on the type of consumer tissue analyzed (Drago et al. 2009, Martínez del Rio et al. 2009). Isotope values either change significantly in a predictable manner as with the stepwise increase in nitrogen $\left(\delta^{15} \mathrm{~N}\right)$ of $\sim 2 \% 00-5 \%$ with each increase in trophic level (Vanderklift and Ponsard 2003), or as with carbon $\left(\delta^{13} \mathrm{C}\right)$ they remain relatively constant and thus indicate the sources of nutrients in the food web (Peterson and Fry 1987, Hobson et al. 1997). Consumers usually excrete the lighter isotope $\left(\right.$ e.g.,${ }^{12} \mathrm{C}$ or $\left.{ }^{14} \mathrm{~N}\right)$ and use the heavier isotope $\left(\right.$ e.g.,${ }^{13} \mathrm{C}$ or $\left.{ }^{15} \mathrm{~N}\right)$ to synthesize tissues (Owens 1987). Thus consumers have higher isotope values than their prey, a process commonly referred to as trophic discrimination. The stepwise enrichment 
of ${ }^{15} \mathrm{~N}$ with increasing trophic level makes it possible to examine dietary shifts as animals mature, such as the shift from milk to solid food during weaning or shifts between juvenile and adult diet that might be attributed to differences in phenotype or physiology. In contrast, carbon isotope values in the marine environment are not as sensitive to trophic level, but rather are more directly affected by physicochemical and biological factors that act at the base of the food web. In general, $\delta^{13} \mathrm{C}$ values increase from marine to fresh waters, offshore to nearshore areas, pelagic to benthic depths, and high to middle latitudes within marine ecosystems (Rau et al. 1982, Fry and Sherr 1984, Schell et al. 1989, Wada et al. 1991, France 1995, Hobson et al. 1997, Burton and Koch 1999, Kelly 2000, Newsome et al. 2010). Therefore, it is possible to assess age-related differences or changes in foraging habitats by conspecifics (e.g., adult-benthic foragers, young-epipelagic foragers; Drago et al. 2009).

The isotopic composition of a consumer's tissues is derived from food assimilated over a period of time, and the duration of that period depends on the turnover (or incorporation) rate of the tissue in question (Tieszen et al. 1983, Hobson et al. 1996, Kurle 2002, Kurle and Worthy 2002; see review by Martínez del Rio et al. 2009). Therefore, isotopic analysis of multiple tissues from the same individual can provide dietary information over a variety of temporal scales (Phillips and Eldridge 2006, Martínez del Rio et al. 2009). Little information is known about the diet and habitat use of immature California sea lions. We used stable isotope analysis to examine ontogenetic changes in the diet of individuals at different stages of development as they transitioned from dependent pups to weaned, mature individuals. We used $\delta^{15} \mathrm{~N}$ data to determine the timing of weaning and subsequent age-related changes in trophic level. Additionally, we integrated satellite telemetry data with $\delta^{13} \mathrm{C}$ data to examine habitat use by different-aged individuals.

\section{MATERIALS AND METHODS}

\section{Field Collection}

Individuals that were previously branded for population-dynamics studies by the Alaska Fisheries Science Center's National Marine Mammal Laboratory (Seattle, WA) were targeted because their ages were known. Age class was assigned to non-marked individuals based on each animal's morphological characteristics as follows: pups of both sexes, less than $1 \mathrm{yr}$ old, $<1-1.1 \mathrm{~m}$ in length, dark brown to black in coloration; yearlings of both sexes, 1-2 yr old, approximately $1-1.25 \mathrm{~m}$ in length, tan to light brown in coloration; juveniles of both sexes, approximately $2-4 \mathrm{yr}$ old, $1-1.5 \mathrm{~m}$ in length, dark gray to brown in coloration; adult females, $\geq 4 \mathrm{yr}$ old, $1.5-2 \mathrm{~m}$ in length, light brown or cream colored; and adult males, $\geq 9 \mathrm{yr}$ old, $2-2.5 \mathrm{~m}$ long, dark brown or black, well-developed sagittal crest (descriptions summarized from Aurioles-Gamboa 1988, Aurioles-Gamboa and Zavala 1994).

Tissues (i.e., fur, red blood cells (RBCs), blood plasma, and/or serum) were collected from immature (i.e., pup, yearling, and juvenile) and adult female California sea lions at San Miguel Island, California $\left(34.03^{\circ} \mathrm{N}, 120.44^{\circ} \mathrm{W}\right)$, during 2004 through 2007 (Table 1, Appendix S1). Additionally, fur samples were collected from adult male sea lions at Shilshole Bay, Seattle, Washington $\left(47.68^{\circ} \mathrm{N}, 122.40^{\circ} \mathrm{W}\right)$, during May 2006. The growth rate of fur is slower than turnover rates of blood components (i.e., metabolically active tissues), and RBCs have slower turnover rates than serum or plasma (Tieszen et al. 1983, Hobson and Clark 1993, Hilderbrand et al. 1996, Klaassen et al. 2004). Therefore, the isotopic measurement of fur should provide 
Table 1. Number of samples for stable isotope analyses obtained from California sea lions at San Miguel Island, California, or Shilshole Bay, Washington (adult male only), during 2004 through 2007 by age class, sex, and tissue type. Sampling months by age class are indicated in the footnote.

\begin{tabular}{llrrrr}
\hline \hline Age class & \multicolumn{1}{c}{ Sex } & Fur & Plasma & RBC & Serum \\
\hline Pup & Female $(n=122)$ & 103 & 32 & 30 & 60 \\
$(<1$ yr $)$ & Male $(n=103)$ & 82 & 36 & 36 & 62 \\
& Unknown $(n=3)$ & 3 & 2 & 2 & 3 \\
Yearling & Female $(n=8)$ & 8 & 6 & 6 & 8 \\
$(1-2$ yr) & Male $(n=2)$ & 2 & 2 & 1 & 2 \\
Juvenile & Female $(n=17)$ & 17 & 14 & 12 & 16 \\
$(2-4$ yr $)$ & Male $(n=1)$ & 1 & 0 & 0 & 1 \\
Adult & Female $(n=23)$ & 23 & 16 & 15 & 0 \\
$(\geq 4$ yr $)$ & Male $(n=10)$ & 10 & 0 & 0 & 0 \\
\hline
\end{tabular}

Months sampled-Pup: January, August, September, October 2004; February, March, April, October, November 2005; February, July, September, November 2006; January 2007. Yearling: March, Aprril 2005; July, November 2006. Juvenile: March, April, November 2005; August, November 2006. Adult: April, November 2005; May (male), November 2006.

long-term dietary information reflecting integration over several months. For animals that undergo an annual molting cycle like all otariids (assuming the entire shaft was collected and completely homogenized), the isotopic signature of fur will reflect diet since the previous molt. For pinnipeds, plasma and serum have high turnover rates and are likely to provide dietary information from 1 to $2 \mathrm{wk}$ prior to collection (Kurle 2002), whereas RBCs are likely to represent the average isotopic composition of diet integrated over two or more months (Kurle 2002, Zhao et al. 2006).

Fur was obtained from live or recently dead (in rigor mortis) individuals by cutting a patch (approximately $2 \mathrm{~cm} \times 2 \mathrm{~cm}$ ) on the dorsal side of each animal at the pelvic girdle using electric clippers or scissors applied to the base of the fur without removing the follicle. Samples were stored dry in paper envelopes until further processing in the laboratory. Blood samples were obtained during routine collections from the caudal-gluteal vein using a 1.5 in $(3.81 \mathrm{~cm}) 20$-gauge hypodermic needle and placed directly into Vacutainer tubes. Plasma and RBCs were collected in tubes containing the anticlotting agent sodium heparin, which has been determined not to alter isotopic values (Hobson et al. 1997, Kurle 2002). Serum was collected from tubes containing a clot activator for serum separation, also known not to cause isotopic alterations (Kurle 2002). Plasma, serum, and RBCs were obtained after $10 \mathrm{~min}$ of centrifugation. Approximately $1 \mathrm{~mL}$ of each component was decanted into a $2 \mathrm{~mL}$ cryovial and frozen until further processing in the laboratory.

\section{Stable Isotope Analysis}

Once in the laboratory, fur samples were placed in scintillation vials and cleaned by washing them with a mild detergent solution, followed by a rinse with deionized (DI) water. Surface contaminants were removed using a solvent wash (chloroform:methanol, 2:1, v/v) and another DI water rinse. Samples were then placed in a lyophilizer and dried for 24-48 h. Frozen blood samples also were placed into the lyophilizer. Once dried, all samples were ground into powder and homogenized 
using a mortar and pestle (fur) or glass rod (blood components). Samples were weighed into tin capsules $(8 \mathrm{~mm} \times 5 \mathrm{~mm})$ to a target weight of $1.0 \pm 0.2 \mathrm{mg}$.

$\delta^{13} \mathrm{C}$ and $\delta^{15} \mathrm{~N}$ isotope values of most tissues (540/636) analyzed in this study were determined using a Carlo-Erba elemental analyzer (NC 2500) interfaced with a Finnegan Delta Plus XL mass spectrometer in the light stable isotope facility at Carnegie Institution of Washington (Washington, DC). Ninety-six fur samples collected during 2004 and 2005 were analyzed using a continuous flow isotope ratio mass spectrometer (20-20 PDZ Europa) at the University of California at Davis Stable Isotope Facility (Davis, CA). Standards of known isotopic composition were analyzed at each facility to correct for inter-laboratory differences. Isotopic results are expressed as $\delta$ values, $\delta^{13} \mathrm{C}$ or $\delta^{15} \mathrm{~N}=1,000^{*}\left[\left(R_{\text {sample }} / R_{\text {standard }}\right)-\right.$ $1]$, where $R_{\text {sample }}$ and $R_{\text {standard }}$ are the ${ }^{13} \mathrm{C} /{ }^{12} \mathrm{C}$ or ${ }^{15} \mathrm{~N} /{ }^{14} \mathrm{~N}$ ratios of the sample and standard, respectively. The standards are Vienna-Pee Dee Belemnite limestone (VPDB) for carbon and atmospheric $\mathrm{N}_{2}$ for nitrogen. The units are expressed as per mil $(\% 0)$ and are calibrated to international standards through repeated measurements of a gelatin standard of known isotopic composition. The within-run standard deviation of acetanilide standards was $\leq 0.2 \%$ for both $\delta^{13} \mathrm{C}$ and $\delta^{15} \mathrm{~N}$ values. As a control for tissue quality, we also measured the $[\mathrm{C}] /[\mathrm{N}]$ ratios of each sample (Appendix S1).

Generalized additive models (GAMs) were used to describe changes in isotope ratios with age using samples from known-aged individuals supplemented with 82 adult samples with an unknown but assigned age of $8 \mathrm{yr}$, the approximate mean age of postrecruitment (6-12 yr) for sexually mature California sea lion females (Melin 2002). Females between the ages of $8-15$ yr have the highest birth rates (Hernández-Camacho 2008; NOAA, unpublished data), as well as an established modality of feeding behavior. Finally, survival of adult females decreases around $16 \mathrm{yr}$ of age; therefore, $8 \mathrm{yr}$ arbitrarily represents the mean age of adult females. Although $8 \mathrm{yr}$ old males might not be socially mature, they are sexually mature and they are only 1 yr younger from being classically defined as adults. Therefore, 8 yr was assigned to males as well for consistency. Different GAM models also were fitted to examine the importance of tissue type, sex, and year. The best model was chosen using the minimum Akaike information criterion (AIC), which minimizes prediction error. A stratified analysis of variance (ANOVA) was used to quantify isotopic differences using age class (rather than age to increase sample sizes), sex, and tissue. When significant differences were detected, pairwise multiple comparisons between age classes were assessed using Tukey's Honest Significant Difference (HSD; Zar 1999). Significance level was set at $\alpha=0.05$. Statistical analyses were performed using R (R Development Core Team 2006). The GAMs were fitted with the mgcv package in $\mathrm{R}$ (Wood 2006).

\section{Instrumentation}

To determine foraging locations (reflected by $\delta^{13} \mathrm{C}$ values) of California sea lions, 50 individuals of various age classes were instrumented with satellite transmitters during 2002 through 2007. Animals were physically restrained during attachment of transmitters. Instruments (SirTrack KiwiSat 101 Platform Transmitter Terminal (PTTs; Havelock North, New Zealand)), or Wildlife Computers' SPLASH tag or Smart Positioning or Temperature Transmitting Tag (SPOT 5; Redmond, WA) were attached to the dorsal pelage between the scapulae using Devcon 5 min epoxy. Sea lion locations were collected by the tags and transmitted via the ARGOS satellite system when the animal was at the surface. To extend battery life, the Kiwisat PTTs 
Table 2. GAMs fitted to the $\delta^{15} \mathrm{~N}$ or $\delta^{13} \mathrm{C}$ measurements of California sea lion tissue samples collected at San Miguel Island, California, between 2004 and 2007. s indicates a smooth function applied to the variable and Age*Tissue means that the smooth function of age differed by tissue type. Model selection was based on minimum AIC.

\begin{tabular}{lll}
\hline \hline & \multicolumn{2}{c}{ AIC } \\
\cline { 2 - 3 } Generalized additive model & $X=\delta^{15} \mathrm{~N}$ & $X=\delta^{13} \mathrm{C}$ \\
\hline gam $1=\operatorname{gam}\left(X \sim \mathrm{s}^{2}\left(\right.\right.$ age $^{*}$ tissue $)+$ tissue $)$ & 726.1 & 626.3 \\
gam $=\operatorname{gam}\left(X \sim \mathrm{s}^{*}\right.$ tissue $)+$ tissue $\left.+\mathrm{sex}\right)$ & 727.3 & 624.5 \\
$\operatorname{gam} 3=\operatorname{gam}(X \sim \mathrm{s}($ age $)+$ tissue + year $)$ & 808.1 & 672.8 \\
$\operatorname{gam} 4=\operatorname{gam}(X \sim \mathrm{s}($ age $)+$ tissue + sex $)$ & 811.3 & 724.8 \\
$\operatorname{gam} 5=\operatorname{gam}(X \sim \mathrm{s}($ age $)+$ tissue $)$ & 809.3 & 731.2 \\
\hline
\end{tabular}

were programmed with an $8 \mathrm{~h}$ ( $4 \mathrm{on} / 4$ off) duty cycle. To maximize the number of transmission received by Argos satellites, tag transmission periods were synchronized with periods of optimal satellite coverage. Transmitters sent a signal every $45 \mathrm{~s}$ when the tag breached the water surface. Locations for each individual were evaluated by comparing the distance and time elapsed between successive locations given a maximum speed of $7.2 \mathrm{~km} / \mathrm{h}$ (Feldkamp et al. 1989, McConnell et al. 1992). After filtering potential outliers (i.e., locations that exceeded the plausible distance of travel given the period of time), all remaining locations were retained for analysis. Location data were incorporated in a continuous-time correlated random walk model to predict hourly locations using the crawl package in $\mathrm{R}$ (Johnson et al. 2008). In addition to examining location data, home range areas were estimated as the minimum convex polygon (MCP) from pooled locations for each age class. Kernel density plots were created to provide a summary of the structure of the location data and its density function. These plots were created using the Kernel Density tool in the Spatial Analyst Tools extention in ArcGIS (ver. 10.0; Environmental Systems Research Institute, Inc., Redlands, CA).

\section{RESULTS}

A total of 630 tissue samples were collected from 289 California sea lions (Table 1, Appendix S1). Approximately 89\% of the individuals were of known age (to the nearest month). Because of an extremely small sample of known-aged adults $(n=1)$, the unknown-aged adult animals ( $n=32 ; 82$ tissue samples) were assigned the age of $8 \mathrm{yr}$ in the GAM models (see Materials and Methods). Results were relatively consistent when younger and older ages were substituted. The best GAM model included different smooth functions of age by tissue and tissue-dependent intercepts for both $\delta^{15} \mathrm{~N}$ and $\delta^{13} \mathrm{C}$ (Table 2). The best model for $\delta^{13} \mathrm{C}$ and the second best model for $\delta^{15} \mathrm{~N}$ also included a sex effect. At 8 mo of age for blood components and 20 mo for fur, $\delta^{15} \mathrm{~N}$ began to decline precipitously (Fig. 1). In contrast, $\delta^{13} \mathrm{C}$ values generally increased with age, but the patterns were variable and not consistent among tissues (Fig. 2). Fur $\delta^{15} \mathrm{~N}$ and $\delta^{13} \mathrm{C}$ values were significantly different from those of the blood components (GAM; for all comparisons, $P<0.05$ ). There were no significant differences in $\delta^{15} \mathrm{~N}$ or $\delta^{13} \mathrm{C}$ values by sex (GAM; for all comparisons, $P>0.06)$. 


\section{Fur}

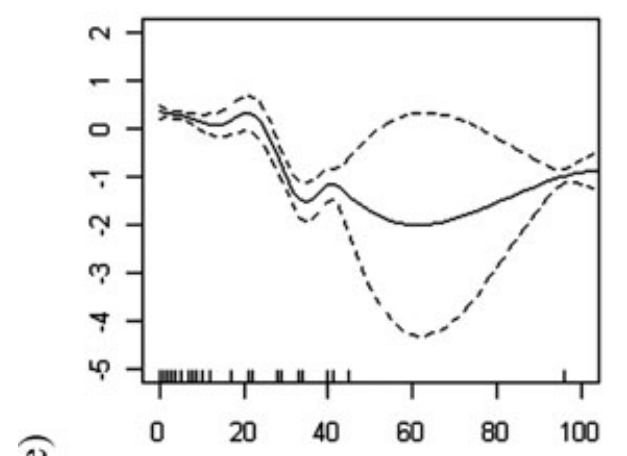

Serum

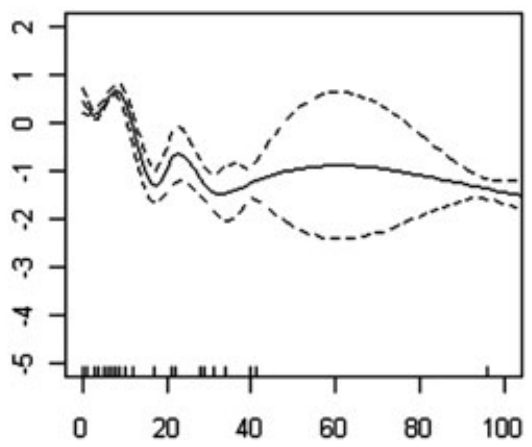

$\mathrm{RBC}$

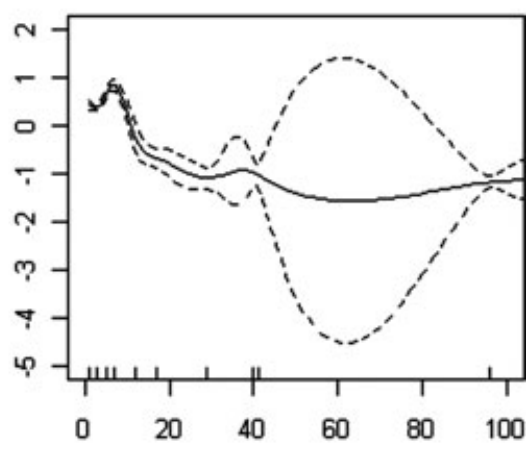

Plasma

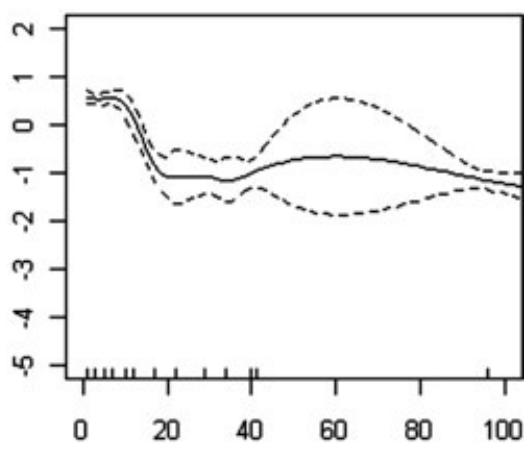

\section{Age (month)}

Figure 1. Plots of GAMs of $\delta^{15} \mathrm{~N}$ by age for each tissue type collected from California sea lions during 2004 through 2007 at San Miguel Island, California. $X$-axis denotes age (in months) and $y$-axis denotes relative distance from the mean. Dashed lines indicate variation. Vertical ticks on the abscissa represent actual ages at which animals were sampled.

For each tissue type, immature animals were ${ }^{15} \mathrm{~N}$-enriched compared to older animals (Fig. 3). The lowest and highest mean $\delta^{15} \mathrm{~N}$ values were $16.6 \%$ (RBC, Adult) and 19.6\% (Serum, Pup; Fig. 3), respectively. Pups were ${ }^{15} \mathrm{~N}$-enriched between $1.3 \%$ and $1.9 \%$ compared to adults depending on tissue type, indicating that they were suckling. An opposite trend was observed for $\delta^{13} \mathrm{C}$; younger age classes generally had lower values (Fig. 3). $\delta^{13} \mathrm{C}$-values ranged from $-15.5 \% 0$ (Serum, Pup) to $-13.2 \%$ (Fur, Adult; Fig. 3). Pups were ${ }^{13} \mathrm{C}$-depleted between $-0.9 \%$ and $-0.3 \%$ compared to adults when fur, plasma, and serum were analyzed. However, pups were ${ }^{13} \mathrm{C}$-enriched by $0.4 \%$ compared to adults when RBCs were used.

$\delta^{15} \mathrm{~N}$ values differed among age classes (ANOVA: $F_{3,617}=455.52, P<0.05$ ), but not between sexes (ANOVA: $F_{1,617}=0.003, P=0.95$ ). Post hoc comparisons indicated that there were no differences in $\delta^{15} \mathrm{~N}$ values between juveniles and adults for all tissues, and between yearlings and juveniles for plasma and serum (Tukey's HSD: for all comparisons, $P>0.09)$; however, $\delta^{15} \mathrm{~N}$ values of all blood components 


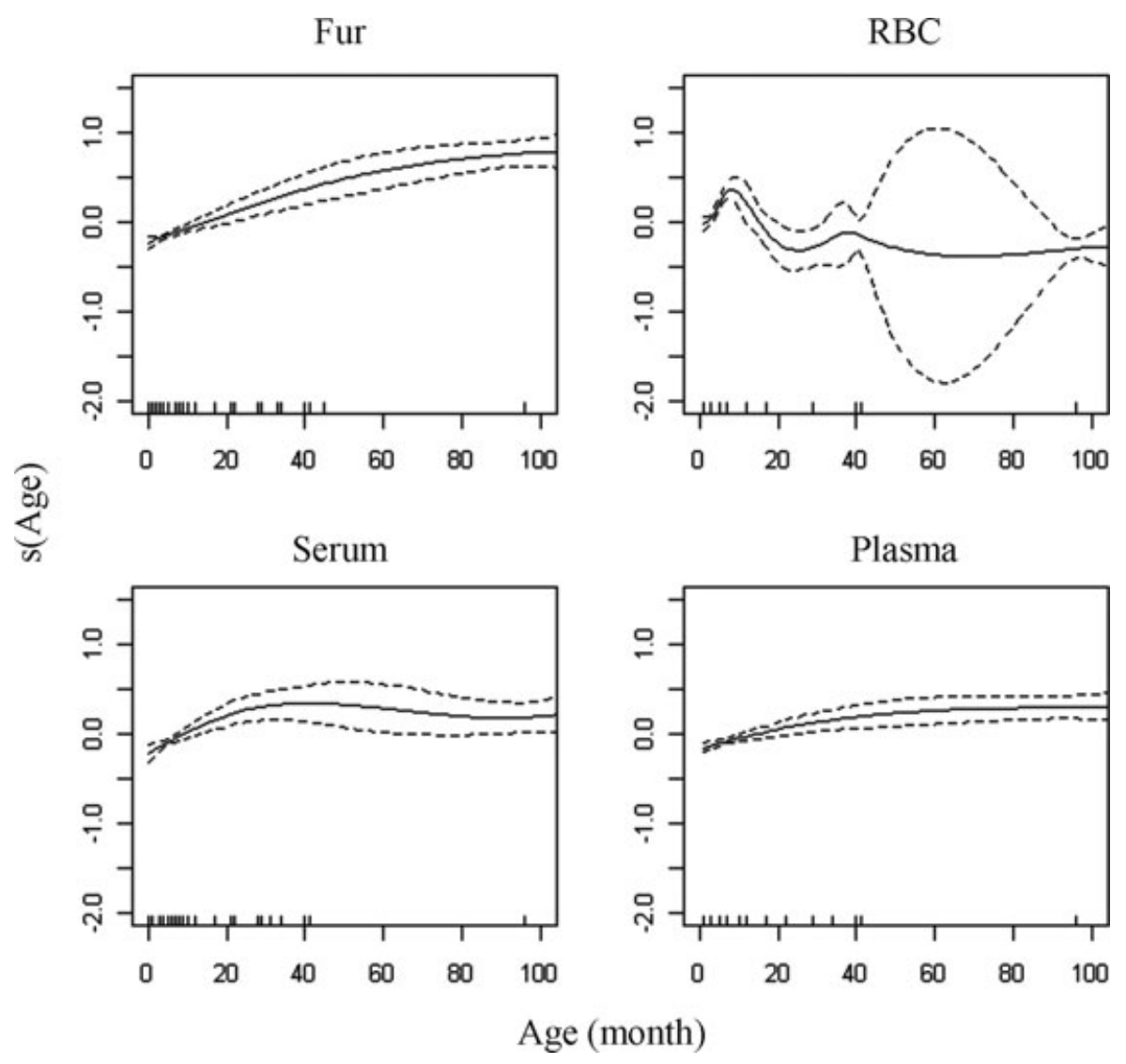

Figure 2. Plots of GAMs of $\delta^{13} \mathrm{C}$ by age for each tissue type collected from California sea lions during 2004 through 2007 at San Miguel Island, California. X-axis denotes age (in months) and $y$-axis denotes relative distance from the mean. Dashed lines indicate variation. Vertical ticks on the abscissa represent actual ages at which animals were sampled.

were higher for pups than all older age classes (Tukey's HSD: for all comparisons, $P<$ 0.05). $\delta^{13} \mathrm{C}$ values differed among age classes (ANOVA: $F_{3,617}=20.60, P<0.05$ ) and between sexes, although minimally (ANOVA: $F_{1,617}=4.70, P=0.03$ ). Post hoc comparisons indicated that pups had significantly lower $\delta^{13} \mathrm{C}$ values compared to older age classes except for yearlings when fur and RBCs were examined (Tukey's HSD: for all comparisons, $P<0.05)$. Adults had significantly higher $\delta^{13} \mathrm{C}$ fur values compared to yearlings and juveniles (Tukey's HSD: for all comparisons, $P<0.04$ ); however, no other older age-class comparisons were significantly different (Tukey's HSD: for all comparisons, $P>0.05$ ).

It should be noted that although there were inter- and intraannual differences in $\delta^{15} \mathrm{~N}$ and $\delta^{13} \mathrm{C}$ values within age classes, the magnitude of differences were relatively small $(<0.5 \%)$ for most monthly and annual comparisons. Additionally, no particular month or year had consistently higher or lower $\delta^{15} \mathrm{~N}$ and $\delta^{13} \mathrm{C}$ values 

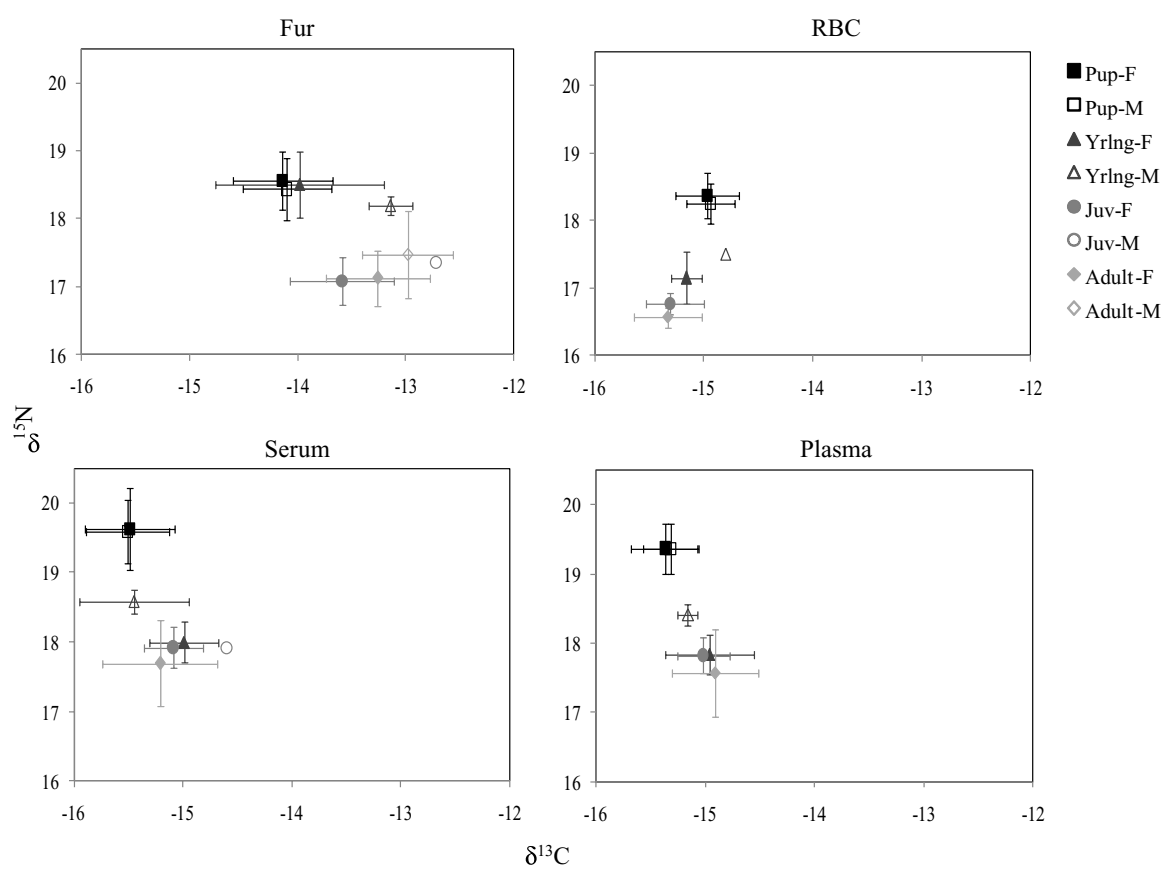

Figure 3. The relationship between mean $\delta^{13} \mathrm{C}$ and $\delta^{15} \mathrm{~N}$ of blood and fur tissues collected from California sea lions of various age classes and sexes at San Miguel Island, California, during 2004 through 2007. Error bars represent one standard deviation from the mean.

across age classes. Therefore, inter- and intraannual isotopic differences should be recognized, however changes are likely due to individual dietary variation.

\section{Location Data}

Satellite transmitters were attached to 30 pup, 8 yearling, and 12 juvenile California sea lions (Appendix S2). The minimum and maximum ages for instrumented individuals were 5 and 41 mo, respectively. A total of 11,013 (75\%) individual locations were retained after filtering the location data received by Argos satellites and subsequently used in the correlated random walk model. Animals were distributed between latitudes $32^{\circ} \mathrm{N}$ and $39^{\circ} \mathrm{N}$ and between longitudes $124^{\circ} \mathrm{W}$ and $118^{\circ} \mathrm{W}$ (Fig. 4). Maximum distances away from San Miguel Island were $344 \mathrm{~km}$ for pups, $521 \mathrm{~km}$ for yearlings, and $617 \mathrm{~km}$ for juveniles, primarily in a northwest direction. Individual yearlings and juveniles traveled north of San Francisco Bay and individual pups traveled as far north as Monterey Bay, California. The areas for the MCP home ranges were $8,610 \mathrm{~km}^{2}$ for pups, $10,130 \mathrm{~km}^{2}$ for yearlings, and $6,521 \mathrm{~km}^{2}$ for juveniles (Fig. 4). Most locations, regardless of age class, were on the continental shelf within the $200 \mathrm{~m}$ isobath $(50.0 \%$ for pups, $79.7 \%$ for yearlings, and $65.7 \%$ for juveniles), with a majority of the remaining locations distributed on the continental slope (Fig. 4). Kernel density plots indicated that animals were distributed around the northern California Channel Islands and in nearshore regions just north of and within the Southern California Bight (Fig. 4). 

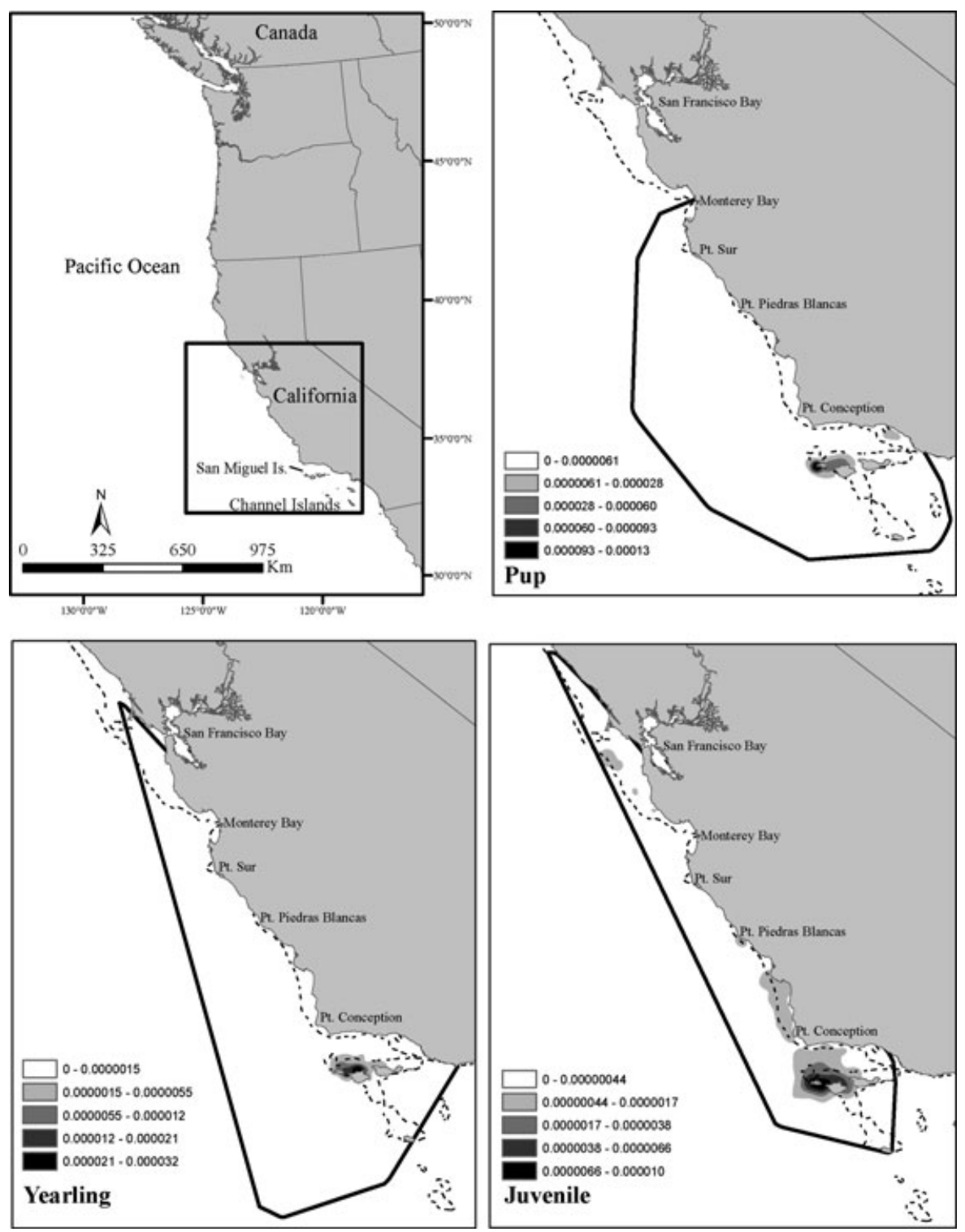

Figure 4. Kernel density plots and home-range defined by MCPs for immature California sea lions instrumented at San Miguel Island, California, during 2002 through 2007. Plots were derived from at-sea location data $\left(n_{\text {pup }}=59,129, n_{\text {yrl }}=14,112, n_{\text {juv }}=15,824\right)$ predicted with a continuous-time correlated random walk model. The legend indicates classified density (locations $\mathrm{m}^{-2}$ ). MCPs are represented by solid black line. The continental shelf is defined by the $200 \mathrm{~m}$ isobath is indicated by dashed black line. 


\section{DisCUSSION}

Isotopic information provided here does not permit an actual reconstruction of the diet of California sea lions primarily because of the lack of isotope data for common prey taxa. In order to assess diet composition, an isotopic "prey map" is needed, which was beyond the scope of this study. However, our data were useful in elucidating changes in assimilated diet corresponding to maturation of sea lions.

Aurioles-Gamboa et al. (2009) noted that there are three essential determinants of isotopic values in marine predators, including physiology (which influences diet-totissue discrimination), diet, and foraging location. Differences in age and tissue type were important factors in explaining the variation in stable isotope values reported in this study. Besides being indicative of changes in dietary intake and trophic level at different time scales, discrepancies in $\delta^{13} \mathrm{C}\left(\right.$ and $\left.\delta^{15} \mathrm{~N}\right)$ values among tissues of an individual could be driven by ecological factors like temporal shifts in diet and/or habitat use or may reflect biochemical differences in the amino acid composition or lipid content in the tissues (Kurle 2002, Zhao et al. 2006). Results from studies on captive birds and mammals indicated that isotope values of different tissues from the same individual do vary in a systematic way, even when the animal is fed an isotopically homogenous diet (Kurle 2002, Vanderklift and Ponsard 2003, De Smet et al. 2004, Sponheimer et al. 2006, Zhao et al. 2006). For example, serum albumin is the major carrier of fatty acids in blood (Nelson 1970), and lipids are ${ }^{13} \mathrm{C}$-depleted in comparison to associated proteins (Kelly 2000), which results in lower $\delta^{13} \mathrm{C}$ values (Kurle 2002) in serum relative to other tissues. Unlike captive individuals, wild sea lions typically do not have an isotopically homogeneous diet, therefore changes in their diet (prey species, acquisition location) and tissue composition must be factored in explaining differences in $\delta^{13} \mathrm{C}$ and $\delta^{15} \mathrm{~N}$ values among different tissues. In our study there were differences in isotope values among most of the tissues analyzed, the only exception being plasma and serum, which are very similar in biochemical composition except plasma contains fibrinogen and other clotting-factor proteins (Schier et al. 1996). Regardless of tissue used in this study, observed ontogenetic shifts in isotope values were consistent with recognized ${ }^{15} \mathrm{~N}$ enrichment related to trophic level and ${ }^{13} \mathrm{C}$ depletion (except for RBCs) with lipid content among the diets of pups, yearlings, juveniles, and adults (Hobson and Sease 1998, Newsome et al. 2006).

Pups had higher $\delta^{15} \mathrm{~N}$ values compared to older animals. This seemed logical because most, if not all, of their diet is milk, which is derived from remobilized tissues of lactating females. In essence, pups were feeding on their mothers' tissues and consequently appear to be feeding at a higher trophic level than older conspecifics. Similar patterns of enrichment of ${ }^{15} \mathrm{~N}$ in tissues of dependent young compared to those of their mothers has been shown in several other studies on humans (e.g., Fogel et al. 1989, 1997), cetaceans (e.g., Knoff et al. 2008), and other pinnipeds (e.g., Hobson et al. 1997, Hobson and Sease 1998, Newsome et al. 2006). As with previous studies (e.g., Jenkins et al. 2001, Polischuk et al. 2001, Newsome et al. 2006), suckling individuals had $\delta^{15} \mathrm{~N}$ values that were equal to or higher than those of premature or newborn animals. The $\delta^{15} \mathrm{~N}$ values observed in this study were similar to those of previous studies that analyzed other tissues of California sea lion pups (Burton and Koch 1999, Aurioles-Gamboa et al. 2006, Newsome et al. 2006, Porras-Peters et al. 2008).

$\delta^{15} \mathrm{~N}$ values remained high during early life stages until a pronounced decline that started around 8-9 mo of age for blood components; values continued to decrease 
until approximately 11-17 mo of age. This weaning signal was indicative of a reduction in the contribution of milk to the diet and that young sea lions were increasingly supplementing their milk diet with food acquired at sea. The different components of blood integrate changes in isotope compositions on the order of days or weeks (plasma and serum) to months (RBCs). The timing of a weaning signal was similar for the components of blood, and was at a higher resolution using these tissues in comparison to using fur. The sharp decline in $\delta^{15} \mathrm{~N}$ values for fur did not appear until around 20 mo of age. California sea lion pups undergo a postnatal molt around September-October (3-4 mo of age), but several individuals have been observed molting during January-February ( $7-8$ mo of age; personal observation). It is not certain if this is a late postnatal or a second molt, thus complicating the interpretation of $\delta^{15} \mathrm{~N}$ patterns in pup fur. The slight decrease in $\delta^{15} \mathrm{~N}$ values in fur from pups starting around 6 to 7 mo of age could reflect a difference in $\delta^{15} \mathrm{~N}$ values of fur acquired in utero and fur obtained after their postnatal molt during which pups were suckling. It should be noted that this pattern may also be an artifact of sampling. The sharp decline of $\delta^{15} \mathrm{~N}$ values of fur observed around $20 \mathrm{mo}$ of age could reflect changes in signatures from their preweaned diet integrated before their first annual molt, to that of the postweaned diet reflected in new fur acquired after their first annual molt.

Yearling mean $\delta^{15} \mathrm{~N}$ values were either intermediate or very similar to adults, depending on the tissue examined. Yearling plasma and serum $\delta^{15} \mathrm{~N}$ values, which represented their most recently integrated diet, indicated that individuals of this age class were feeding on a similar trophic level to juveniles and adults. Previous studies (e.g., Fiscus and Baines 1966; Antonelis et al. 1984, 1990; DeLong et al. 1991; Melin et al. 2008) have indicated that adult sea lions at San Miguel Island frequently feed on Pacific whiting (hake; Merluccius productus), rockfish (Sebastes spp.), northern anchovy (Engraulis mordax), jack mackerel (Trachurus symmetricus), market squid (Loligo opalescens), and red octopus (Octopus rubescens). Many of these species school and inhabit epipelagic areas that even yearling sea lions may be physiologically or morphologically capable to exploit. The intermediate mean $\delta^{15} \mathrm{~N}$ value of yearling males was an artifact of one individual that probably was still suckling because weaned yearlings and nonbreeding juveniles are usually not tolerated in breeding areas. This particular animal was captured on one of the breeding sites and presumed to be still suckling from its mother. Yearling $\mathrm{RBC} \delta^{15} \mathrm{~N}$ values were higher but closer to those of juveniles and adults compared to those of pups. Therefore, their assimilated diet over several months indicated that most individuals were foraging independently but a small portion of their diet (or the diet of a few individuals, which is more likely considering the isotopic variance) contained milk. Yearling fur $\delta^{15} \mathrm{~N}$ values gradually decreased and approached the values of older conspecifics at the end of their second birthday. It was during this second year of life that a transition to independent foraging was observed, several months later than what was reflected using blood components. Tissues that integrate diet over a longer time scale like fur may be masking short-term ecological processes and dietary shifts.

Juvenile and adult sea lions had similar mean $\delta^{15} \mathrm{~N}$ values for all tissues indicating that they were feeding at approximately the same trophic level. From examining fecal samples, Orr et al. (2011) reported that adult female California sea lions ate twice the number of prey taxa as juveniles, however there were five prey species that were dominant in the diet of both groups (northern anchovy, Pacific sardine (Sardinops sagax), Pacific whiting, rockfish, and market squid). Their results also 
indicated that there was an overlap in the size of prey consumed by both age classes. The small differences in mean $\delta^{15} \mathrm{~N}$ values for all tissues between these two age classes may be attributable to adult females having a more diverse diet compared to juveniles. Differences in energetic requirements, development, learning, or prey preferences might be plausible explanations for these discrepancies. The slight $\left(\sim 0.5 \%\right.$ ) enrichment of ${ }^{15} \mathrm{~N}$ in the fur of males of these age classes might suggest they were feeding in different areas on similar prey with slight isotopic differences, or feeding on different proportions of the same prey. Because of physiological or morphological (sexual dimorphic) differences, males could have been consuming larger individuals of the same prey species, which would lead to slightly higher mean $\delta^{15} \mathrm{~N}$ values because body size is positively correlated with nitrogen isotope values in many fish species (Jennings et al. 2001). Additionally, the fur of adult males may have reflected the diet assimilated when the animals were feeding in waters off Washington. These animals could have been feeding on different prey compared to the other age and sex classes but still feeding at a similar trophic level.

Contradictory to $\delta^{15} \mathrm{~N}$ values, pups had lower mean $\delta^{13} \mathrm{C}$ values for all tissues (except RBCs) compared to older individuals. Lower $\delta^{13} \mathrm{C}$ values in pup fur, plasma, and serum were likely a result of the high lipid content in milk. Lipids are depleted in ${ }^{13} \mathrm{C}$ compared to other macromolecular dietary components (Tieszen et al. 1983, Tieszen and Boutton 1988, Polischuk et al. 2001, Kurle 2002). The enrichment of ${ }^{13} \mathrm{C}$ resulting from a change from a lipid-rich milk to a protein-based solid diet has been reported in other studies of mammals (e.g., Hobson and Sease 1998, Jenkins et al. 2001, Polischuk et al. 2001, Newsome et al. 2006, Knoff et al. 2008, Drago et al. 2009). Two of these studies (Hobson and Sease 1998, Newsome et al. 2006) examined tooth dentin and bone collagen in sea lions and observed lower $\delta^{13} \mathrm{C}$ values $(\sim 2 \%$ ) for young age classes when the animals were suckling lipid-rich milk, compared to older dental layers formed when individuals were probably consuming a ${ }^{13} \mathrm{C}$-enriched protein based diet. However, this pattern was not consistent among pinnipeds because some species examined nurse their young from as little as 1 mo (e.g., northern elephant seal, Mirounga angustirostris) to more than 10 mo (e.g., Steller sea lion, Eumetopias jubatus). The opposite trend was observed when RBCs were used to examine mean $\delta^{13} \mathrm{C}$ values by age class in this study. The inconsistent nature of $\delta^{13} \mathrm{C}$ values among tissues has been documented in other studies of mammals (Wright and Schwarcz 1999, Fuller et al. 2003).

Unlike $\delta^{15} \mathrm{~N}$, there did not appear to be a pronounced change in $\delta^{13} \mathrm{C}$ values of sea lions thus signaling when weaning or other age-dependent changes in diet might have occurred. This may be due to the differences in the magnitude of the signal between the two isotope systems. $\delta^{15} \mathrm{~N}$ values varied more than twice as much as $\delta^{13} \mathrm{C}$ values between preweaned pups and weaned individuals. Kurle (2002) noted that the discrimination of carbon isotopes between trophic levels is small, limiting its use as a trophic indicator. However, $\delta^{13} \mathrm{C}$ can be used to approximate an animal's foraging habitat (Hobson and Sease 1998, Kurle and Worthy 2001, Hobson 2005, Aurioles-Gamboa et al. 2006). Therefore, the differences in mean $\delta^{13} \mathrm{C}$ values among juvenile and adult individuals may reflect where they predominately foraged.

The general geographic patterns for $\delta^{13} \mathrm{C}$ in marine environments include lower $\delta^{13} \mathrm{C}$ values with higher latitudes, and higher $\delta^{13} \mathrm{C}$ values in benthic vs. pelagic and nearshore $v$ s. offshore habitats (McConnaughey and McRoy 1979, France 1995, Hobson 2005). Aurioles-Gamboa et al. (2006) reported a 1\%o increase in particulate organic matter (POM) $\delta^{13} \mathrm{C}$ values for every $5^{\circ}$ decrease in latitude along the eastern Pacific Ocean. Locations of individuals (grouped by age class) did not extend beyond 
$5^{\circ}$ of latitude, so any differences in $\delta^{13} \mathrm{C}$ values of postweaned individuals would more likely be attributable to differences in benthic/pelagic or nearshore/offshore foraging habitats.

The slightly higher mean $\delta^{13} \mathrm{C}$ values (fur and serum) for juvenile males might reflect that they were feeding closer to shore than other groups of animals, however, the differences were more likely an artifact of the low sample size $(n=2)$ for this age/sex class. Adult males also had slightly higher mean fur $\delta^{13} \mathrm{C}$ values compared to other groups of sea lions. This contradicts the general latitudinal trend in baseline $\delta^{13} \mathrm{C}$ values because adult males were sampled in Shilshole Bay, Seattle, Washington, $\sim 1,800 \mathrm{~km}$ north of San Miguel Island. Fur samples of adult males were obtained during spring, thus $\delta^{13} \mathrm{C}$ values reflected adult male diet assimilated since November, which is the peak molting month for this age class. Most adult males would have finished their migrations prior to November and would have been foraging in areas near Washington and British Columbia, Canada. The higher $\delta^{13} \mathrm{C}$ values of fur for adult males could be attributed to their feeding in inland waters (e.g., Strait of Juan de Fuca, Puget Sound, Strait of Georgia), or at a higher trophic level; however, they also might be due to the low number of samples $(n=10)$ collected.

With the exception of fur, there were no significant differences in $\delta^{13} \mathrm{C}$ values of yearlings, juveniles, and adults. Therefore, on short and intermediate time scales, individuals within these age classes were feeding in similar habitats. Findings here differ than those of Drago et al. (2009) who examined ontogenetic dietary changes in South American sea lions (Otaria byronia) and reported that apart from senile males, $\delta^{13} \mathrm{C}$ values steadily increased with developmental stage (young, first adult, adult, and senile). They indicated that these results were due to an increase in consumption of benthic prey from postweaning to adulthood, supporting the idea that early foraging ontogeny is tied to improvements in diving skills. Physiological factors that limit diving skills (i.e., foraging behaviors) in pinnipeds are highly correlated with an animal's mass and age (Horning and Trillmich 1997a). Although younger animals are constrained to the depths that they can dive and the duration they can spend at depth compared to older animals, immature California sea lions might have attained sufficient physiological capabilities to forage in similar habitats as adults. Kernel density plots indicated that pups, yearlings, and juveniles were primarily distributed in areas around the northern California Channel Islands and on the continental shelf just north and south of Point Conception, California. Distribution range increased with age class, but latitudinal differences were not large enough to result in large differences in $\delta^{13} \mathrm{C}$ values that would indicate that animals were feeding in different habitats. Previous studies have noted that lactating females are non-migratory and make short foraging trips $(2-3 \mathrm{~d})$ that are primarily over the continental shelf (Feldkamp et al. 1989, Antonelis et al. 1990). Melin et al. (2008) found similar patterns; however, they noted that lactating females traveled farther from the colony and fed exclusively offshore during El Niño Southern Oscillation (ENSO) events. Our study was not conducted during any major ENSO events, so it was likely that adult females primarily foraged in areas on the continental shelf, similar to younger conspecifics.

Several researchers have shown that dive depths of California sea lions increase with age, however most dives were described as shallow $(<75 \mathrm{~m})$ during non-ENSO events (Antonelis et al. 1984, Feldkamp et al. 1989, Melin et al. 2008). In general, California sea lions can be classified as nearshore, epipelagic foragers. The similarities in $\delta^{13} \mathrm{C}$ values among yearlings, juveniles, and adults suggest that these groups of animals fed in similar habitats or the spatial distance between their foraging areas 
was not great enough to reflect spatial differences in the isotopic composition of phytoplankton at the base of the food web.

Isotopic $\left(\delta^{15} \mathrm{~N}\right.$ and $\left.\delta^{13} \mathrm{C}\right)$ variation was heterogeneous within and among age classes. This may be indicative of differences in individual prey preferences at different temporal scales (i.e., intraindividual variability) or differences in diet composition among conspecifics. California sea lions are considered generalists and opportunistic foragers; however their diet has usually been examined at the population level. Individual specialization may be more pervasive than previously thought. Stable isotopes have been used to examine diet specialization in other predators that consume a diverse array of prey like California sea otters (Enhydra lutris nereis; Newsome et al. 2009) and may be useful for elucidating the inter- and intraage class patterns in isotopic variation.

In summary, the decreases in $\delta^{15} \mathrm{~N}$ and increases of $\delta^{13} \mathrm{C}$ values in tissues from preweaned pups to weaned, mature animals reflected a switch in diet from mother's milk to fish and cephalopods acquired at sea and subsequent dietary changes that might be linked to the development of foraging capabilities and skills. We were fortunate to sample individuals of known age throughout this study, and stable isotopes (in particular, $\delta^{15} \mathrm{~N}$ ) provided information about ontogenetic shifts in the diet of this species. By analyzing tissues with a high metabolic or turnover rate (i.e., plasma and serum), we were able to examine the diet of sea lions and identify a weaning signal on a monthly scale, which provides a finer temporal scale in comparison to previous studies that used fur, teeth annuli, or bone collagen. It appears that the onset of weaning begins around 8 mo of age; however, the transition to an adult diet was gradual, and some individuals were still suckling after their first birthday. This corresponds to the reproductive strategies of most otariids (13 of 15 species), and provides a period for young animals to develop diving and foraging skills before they are completely weaned. The approximate age of weaning based on the isotopic proxy $(\sim 8 \mathrm{mo})$ corresponds well with observed attendance patterns of adult females and pups at San Miguel Island (Melin 1995, Melin et al. 2000). In general, it appeared that weaned individuals (especially juveniles and adults) fed on similar trophic levels and in similar foraging areas. However, there was variability in both $\delta^{15} \mathrm{~N}$ and $\delta^{13} \mathrm{C}$ values among age classes, indicating that prey taxa, composition, and/or location of acquisition might have varied by age class (or individuals therein), which might have been linked to differences in physiology, energetic requirements, or learning. The satellite telemetry data was useful for elucidating the patterns of isotopic data (especially $\delta^{13} \mathrm{C}$ ). It was assuring to note that the similarities of $\delta^{13} \mathrm{C}$ values among weaned animals reflected similarities in their at-sea locations. With additional samples from males of all ages, known-aged juveniles and adults of both sexes, and a better examination of individual variation, a more thorough understanding of temporal dietary shifts among ages and between sexes (especially those that are sexually dimorphic) may be attained.

\section{ACKNOWLEDGMENTS}

We thank S. Melin, A. Pecharich, H. Ziel, J. Scordino, R. Jenkinson, T. Goldstein, F. Gulland, G. Orr, B. Roca, and C. Kuhn for their help in the field. Thanks are extended to the Channel Islands National Park Service and Channel Islands Aviation for logistical support. Special thanks go to Ranger I. Williams of the National Park Service for logistical and field support. This manuscript was greatly improved by comments from T. Zeppelin, S. Melin, 
and three anonymous reviewers. Our study was conducted in accordance with NMFS Permits Nos. 781-1613 and 782-1812-00. Reference to trade names does not imply endorsement by the National Marine Fisheries Service, NOAA, or the University of Washington.

\section{LiteratURE Cited}

Antonelis, G. A., C. H. Fiscus and R. L. DeLong. 1984. Spring and summer prey of California sea lions, Zalophus californianus, at San Miguel Island, California, 1978-79. Fishery Bulletin 82:67-76.

Antonelis, G. A., B. S. Stewart and W. F. Perryman. 1990. Foraging characteristics of female northern fur seals (Callorbinus ursinus) and California sea lions (Zalophus californianus). Canadian Journal of Zoology 68:150-158.

Aurioles-Gamboa, D. 1988. Behavioral ecology of California sea lions in the Gulf of California. Ph.D. dissertation, University of California at Santa Cruz, Santa Cruz, CA. 174 pp.

Aurioles-Gamboa, D., and A. Zavala. 1994. Ecological factors that determine distribution and abundance of the California sea lion Zalophus californianus in the Gulf of California. Ciencias Marinas 20:535-553.

Aurioles-Gamboa, D., P. L. Koch and B. J. Le Boeuf. 2006. Differences in foraging location of Mexican and California elephant seals: Evidence from stable isotopes in pups. Marine Mammal Science 22:326-338.

Aurioles-Gamboa, D., S. D. Newsome, S. Salazar-Pico and P. L. Koch. 2009. Stable isotope differences between sea lions (Zalophus) from the Gulf of California and Galápagos Islands. Journal of Mammalogy 90:1410-1420.

Baker, J. D. and M. J. Donohue. 2000. Ontogeny of swimming and diving in northern fur seal (Callorbinus ursinus) pups. Canadian Journal of Zoology 78:100-109.

Burns, J. M. 1999. The development of diving behavior in juvenile Weddell seals: Pushing physiological limits in order to survive. Canadian Journal of Zoology 77:737-747.

Burton, R. K. and P. L. Koch. 1999. Isotopic tracking of foraging and long-distance migration in northeastern Pacific pinnipeds. Oecologia 119:578-585.

DeLong, R. L., G. A. Antonelis, C. W. Oliver, B. S. Stewart, M. C. Lowry and P. K. Yochem. 1991. Effects of the 1982-83 El Niño on several population parameters and diet of California sea lions on the California Channel Islands. Pages 166-172 in F. Trillmich and K. A. Ono, eds. Pinnipeds and El Niño: Responses to environmental stress. SpringerVerlag, New York, NY.

DeNiro, M. J., and S. Epstein. 1978. Influence of diet on the distribution of carbon isotopes in animals. Geochimica et Cosmochimica Acta 42:495-506.

De Smet, S., A. Balcaen, E. Claeys, P. Boeckx and O. Van Cleemput. 2004. Stable carbon isotope analysis of different tissues of beef animals in relation to their diet. Rapid Communications in Mass Spectrometry 18:1227-1232.

Drago, M., L. Cardona, E. A. Crespo and A. Aguilar. 2009. Ontogenic dietary changes in South American sea lions. Journal of Zoology 279:251-261.

Feldkamp, S. D., R. L. DeLong and G. A. Antonelis. 1989. Diving patterns of California sea lions, Zalophus californianus. Canadian Journal of Zoology 67:872-883.

Fiscus, C. H., and G. A. Baines. 1966. Food and feeding behavior of Steller and California sea lions. Journal of Mammalogy 47:195-200.

Fogel, M. L., N. Tuross and D. W. Owsley. 1989. Nitrogen isotope tracers of human lactation in modern and archaeological populations. Pages 111-117. Annual Report of the Director, Geophysical Laboratory, Carnegie Institution of Washington 1988-1989.

Fogel, M. L., N. Tuross, B. J. Johnson and G. H. Miller. 1997. Biogeochemical record of ancient humans. Organic Geochemistry 27:275-287.

Fowler, S. L., D. P. Costa, J. P. Y. Arnould, N. J. Gales and J. M. Burns. 2007a. Ontogeny of oxygen stores and physiological diving capacity in Australian sea lion. Functional Ecology 21:922-935. 
Fowler, S. L., D. P. Costa and J. P. Y. Arnould. 2007b. Ontogeny of movements and foraging ranges in the Australian sea lion. Marine Mammal Science 23:598-614.

France, R. L. 1995. Carbon-13 enrichment in benthic compared to planktonic algae: Foodweb implications. Marine Ecology Progress Series 124:307-312.

Fuller, B. T., M. P. Richards and S. A. Mays. 2003. Stable carbon and nitrogen isotope variations in tooth dentine serial sections from Wharram Percy. Journal of Archaeological Science 30:1673-1684.

Fry, B., and E. B. Sherr. 1984. $\delta^{13} \mathrm{C}$ measurements as indicators of carbon flow in marine and freshwater ecosystems. Smithsonain Contributions to the Marine Sciences 27:1347.

Hernández-Camacho, C. J., D. Aurioles-Gamboa and L. R. Gerber. 2008. Age-specific birth rates of California sea lion (Zalophus californianus californianus) in the Gulf of California, Mexico. Marine Mammal Science 24:664-676.

Hilderbrand, G. V., S. D. Farley, C. T. Robbins, T. A. Hanley, K. Titus and C. Servheen. 1996. Use of stable isotopes to determine diets of living and extinct bears. Canadian Journal of Zoology 74:2080-2088.

Hobson, K. A. 2005. Using stable isotopes to trace long-distance dispersal in birds and other taxa. Diversity and Distributions 11:157-164.

Hobson, K. A., and R. W. Clark. 1993. Turnover of ${ }^{13} \mathrm{C}$ in cellular and plasma factors of blood: Implications for non-destructive sampling in avian dietary studies. Auk 110: 638-641.

Hobson, K. A., and J. L. Sease. 1998. Stable isotope analyses of tooth annuli reveal temporal dietary records: An example using Steller sea lions. Marine Mammal Science 14:116129.

Hobson, K. A., D. M. Schell, D. Renouf and E. Noseworthy. 1996. Stable carbon and nitrogen isotopic fractionation between diet and tissues of captive seals: Implications for dietary reconstructions involving marine mammals. Canadian Journal of Fisheries and Aquatic Sciences 53:528-533.

Hobson, K. A., J. L. Sease, R. L. Merrick and J. F. Piatt. 1997. Investigating trophic relationships of pinnipeds in Alaska and Washington using stable isotope ratios of nitrogen and carbon. Marine Mammal Science 13:114-132.

Horning, M., and F. Trillmich. 1997a. Ontogeny of diving behavior in the Galapagos fur seal. Behaviour 134:1211-1257.

Horning, M., and F. Trillmich. 1997b. Development of hemoglobin, hematocrit, and erthyrocyte values in Galapagos fur seals. Marine Mammal Science 13:100-113.

Jenkins, S. G., S. T. Partridge, T. R. Stephenson, S. D. Farley and C. T. Robbins. 2001. Nitrogen and carbon isotope fractionation between mothers, neonates, and nursing offspring. Oecologia 129:336-341.

Jennings, S., J. K. Pinnegar, N. V. C. Polunin and T. W. Boon. 2001. Weak cross-species relationships between body size and trophic level belie powerful size-based trophic structuring in fish communities. Journal of Animal Ecology 70:934-944.

Johnson, D. S., J. M. London, M.-A. Lea and J. W. Durban. 2008. Continuous-time correlated random walk model for animal telemetry data. Ecology 89:1208-1215.

Kelly, J. F. 2000. Stable isotopes of nitrogen and carbon in the study of avian and mammalian trophic ecology. Canadian Journal of Zoology 78:1-27.

Klaassen, M., M. Thums and I. D. Hume. 2004. Effects of diet change on carbon and nitrogen stable-isotope ratios in blood cells and plasma of the long-nosed bandicoot (Perameles nasuta). Australian Journal of Zoology 52:635-647.

Kleiber, M. 1975. The fire of life. Robert Krieger, New York, NY.

Knoff, A., A. Hohn, and S. Macko. 2008. Ontogenetic diet changes in bottlenose dolphins (Tursiops truncates) reflected through stable isotopes. Marine Mammal Science 24:128137.

Kooyman, G. L. 1989. Diverse divers: Physiology and behavior. Springer-Verlag, New York, NY. 
Kurle, C. M. 2002. Stable-isotope ratios of blood components from captive northern fur seals (Callorbinus ursinus) and their diet: Applications for studying the foraging ecology of wild otariids. Canadian Journal of Zoology 80:902-909.

Kurle, C. M., and G. A. J. Worthy. 2001. Stable isotope assessment of temporal and geographic differences in feeding ecology of northern fur seals (Callorbinus ursinus) and their prey. Oecologia 126:254-265.

Kurle, C. M., and G. A. J. Worthy. 2002. Variation in stable carbon and nitrogen isotope ratios in northern fur seal (Callorbinus ursinus) tissues: Implications for dietary and migratory reconstructions. Marine Ecology Progress Series 236:289-300.

Martínez del Rio, C., N. Wolf, S. A. Carleton and L. Z. Gannes. 2009. Isotopic ecology ten years after a call for more laboratory experiments. Biological Reviews 84:91111.

McConnell, B. J., C. Chambers and M. A. Fedak. 1992. Foraging ecology of southern elephant seals in relation to the bathymetry and productivity of the Southern Ocean. Antarctic Science 4:393-398.

McConnaughey, T., and C. McRoy. 1979. Food-web structure and the fractionation of carbon isotopes in the Bering Sea. Marine Biology 53:257-262.

Melin, S. R. 1995. Winter and spring attendance patterns of California sea lion (Zalophus californianus) females and pups at San Miguel Island, 1991-1994. M.S. thesis, University of Washington, Seattle, WA. 67 pp.

Melin, S. R. 2002. The foraging ecology and reproduction of the California sea lion (Zalophus californianus californianus). Ph.D. thesis, Univeristy of Minnesota, Twin Cities, MN. $150 \mathrm{pp}$.

Melin, S. R., R. L. DeLong, J. R. Thomason and G. R. VanBlaricom. 2000. Attendance patterns of California sea lion (Zalophus californianus) females and pups during the nonbreeding season at San Miguel Island. Marine Mammal Science 16:169-185.

Melin, S. R., R. L. DeLong and D. B. Siniff. 2008. The effects of El Niño on the foraging behavior of lactating California sea lions (Zalophus californianus californianus) during the nonbreeding season. Canadian Journal of Zoology 86:192-206.

Nelson, G. 1970. The lipid composition of the blood of marine mammals. I. Young elephant seals (Mirounga angustirostris) and harp seals (Pagophilus groenlandicus). Comparative Biochemistry and Physiology 34:109-116.

Newsome, S. D., M. A. Etnier and D. Aurioles-Gamboa. 2006. Using carbon and nitrogen isotope values to investigate maternal strategies in northeast pacific otariids. Marine Mammal Science 22:556-572.

Newsome, S. D., M. T. Clementz and P. L. Koch. 2010. Using stable isotope biogeochemistry to study marine mammal ecology. Marine Mammal Science 26:509-572.

Odell, D. K. 1975. Abundance of California sea lions on San Nicolas Island, California. Wildlife Management 39:729-736.

Orr, A. J., G. R. VanBlaricom, R. L. DeLong, V. H. Cruz-Escalona and S. D. Newsome. 2011. Intraspecific comparison of California sea lion (Zalophus californianus) diet assessed using fecal and stable isotope analyses. Canadian Journal of Zoology 89: 109-122.

Owens, N. J. P. 1987. Natural variations in ${ }^{15} \mathrm{~N}$ in the marine environment. Advances in Marine Biology 24:389-451.

Peterson, B. J., and B. Fry. 1987. Stable isotopes in ecosystem studies. Annual Review of Ecology and Systematics 18:293-320.

Phillips, D. L., and P. M. Eldridge. 2006. Estimating the timing of diet shifts using stable isotopes. Oecologia 147:195-203.

Polischuk, S. C., K. A. Hobson and M. A. Ramsay. 2001. Use of stable-carbon and -nitrogen isotopes to assess weaning and fasting in female polar bears and their cubs. Canadian Journal of Zoology 79:499-2001.

Porras-Peters, H., D. Aurioles-Gamboa, V. H. Cruz-Escalona and P. L. Koch. 2008. Trophic level and overlap of sea lions (Zalophus californianus) in the Gulf of California, Mexico. Marine Mammal Science 24:554-576. 
R Development Core Team. 2006. R: A language and environment for statistical computing. R Foundation for Statistical Computing, Vienna, Austria.

Rau, G. H., R. E. Sweeney and I. R. Kaplan. 1982. Plankton ${ }^{13} \mathrm{C}:{ }^{12} \mathrm{C}$ ratio changes with latitude: Differences between northern and southern oceans. Deep Sea Research 29:10351039.

Schell, D. M., S. M. Saupe and N. Haubenstock. 1989. Natural isotope abundances in bowhead whale (Balaena mysticetus) baleen: Markers of aging and habitat use. Ecological Studies 68:260-269.

Schier, D., J. Butler and R. Lewis.1996. Human anatomy and physiology. McGraw-Hill Companies, Boston, MA.

Schmidt-Nielsen, K. 1984. Scaling: Why is body size so important? Cambridge University Press, Cambridge, UK.

Sponheimer, M., T. F. Robinson, T. E. Cerling, et al. 2006. Turnover of stable carbon isotopes in the muscle, liver, and breath $\mathrm{CO}_{2}$ of alpacas (Lama pacos). Rapid Communications in Mass Spectrometry 20:1395-1399.

Thorson, P. H., and B. J. Le Boeuf. 1994. Developmental aspects of diving in northern elephant seal pups. Pages 271-289 in B. J. Le Boeuf and R. M. Laws, eds. Elephant seals: Population ecology, behavior, and physiology. University of California Press, Berkley, CA.

Tieszen, L. L., and T. W. Boutton. 1988. Stable carbon isotopes in terrestrial ecosystems research. Pages 167-195 in P. W. Rundel, J. R. Ehleringer, and K. A. Nagy, eds. Stable isotopes in ecological research. Springer-Verlag, Berlin, Germany.

Tieszen, L. L., T. W. Boutton, K. G. Tesdahl, and N. A. Slade. 1983. Fractionation and turnover of stable carbon isotopes in animal tissues: Implications for $\delta^{13} \mathrm{C}$ analysis of diet. Oecologia 57:32-37.

Vanderklift, M. A., and S. Ponsard. 2003. Sources of variation in consumer-diet $\delta^{15} \mathrm{~N}$ enrichment: A meta-analysis. Oecologia 136:169-182.

Wada, E., H. Mizutani and M. Minagawa. 1991. The use of stable isotopes for food web analysis. Critical Reviews in Food Science and Nutrition 30:361-371.

Wood, S. N. 2006. Generalized additive models: An introduction with R. Chapman \& Hall/CRC, Boca Raton, FL.

Wright, L. E., and H. P. Schwarcz. 1999. Correspondence between stable carbon, oxygen and nitrogen isotopes in human tooth enamel and dentine: Infant diets at Kaminaljuyu. Journal of Archaeological Science 26:1159-1170.

Zar, J. H. 1999. Biostatistical analysis. Prentice-Hall, Inc., Upper Saddle River, NJ.

Zhao, L., D. M. Schell and M. A. Castellini. 2006. Dietary macronutrients influence ${ }^{13} \mathrm{C}$ and ${ }^{15} \mathrm{~N}$ signatures of pinnipeds: Captive feeding studies with harbor seals (Phoca vitulina). Comparative Biochemistry and Physiology, Part A 143:469-478.

Received: 19 May 2010 Accepted: 12 June 2011

\section{SUPPORTING INFORMATION}

The following supporting information is available for this article online:

Appendix $S 1 . \delta^{15} \mathrm{~N}$ and $\delta^{13} \mathrm{C}(\%)$ values and $[\mathrm{C}] /[\mathrm{N}]$ ratios of fur, RBC, plasma, and serum from 290 California sea lions (Zalophus californianus) sampled from 2004 to 2007 at San Miguel Island, California. Note that Sample number does not correspond to the number of samples $(n=630)$.

Appendix S2. Summary information for 49 California sea lions equipped with ARGOS satellite tags at San Miguel Island, California, during 2002 through 2007. 